\title{
Lack of genetic differentiation of blue spiny lobster Panulirus inflatus along the Pacific coast of Mexico inferred from mtDNA sequences
}

\author{
Francisco Javier García-Rodríguez ${ }^{1,2}$, Ricardo Perez-Enriquez ${ }^{1, *}$ \\ ${ }^{1}$ Centro de Investigaciones Biológicas del Noroeste (CIBNOR), Mar Bermejo 195, Colonia Playa Palo de Santa Rita, \\ La Paz, BCS 23090, Mexico \\ ${ }^{2}$ Present address: Centro Interdisciplinario de Ciencias Marinas-Instituto Politécnico Nacional (CICIMAR-IPN), AP 592, \\ La Paz, BCS 23000, Mexico
}

\begin{abstract}
Blue spiny lobster Panulirus inflatus (Bouvier, 1895) is an economically and ecologically important species along the Pacific coast of Mexico. Because most studies have been done on the local level and conducted to obtain fishery biology data, little is known about population boundaries. Previous analysis showed slight morphometric differences between lobsters along the Baja California Peninsula coast and those from the mainland coast. To determine whether differences are consequences of local variation or reproductive isolation and genetic variations, the genetic structure of $P$. inflatus was determined using sequence data of mtDNA (control region, 12S gene, and 16S gene). Genetic variability (number of haplotypes, haplotype diversity, and nucleotide diversity) for each mtDNA fragment was similar among localities. Nonsignificant differences among localities were revealed (control region: $\Phi$ st $=-0.0027, \mathrm{p}=0.555 ; 12 \mathrm{~S}$ gene: $\Phi \mathrm{st}=-0.0011, \mathrm{p}=0.466 ; 16 \mathrm{~S}$ gene: $\Phi \mathrm{st}=$ $-0.00834, p=0.759)$. Low levels of differentiation in morphology and the absence of variability of genetic structure suggest that the blue spiny lobster represents a panmictic population with phenotypic plasticity. We suggest that the lack of variation in genetic structure is related to oceanographic processes coupled with an extended larval period. Mismatch analysis suggested that the population history is characterized by range expansion.
\end{abstract}

KEY WORDS: Genetic diversity $\cdot$ mtDNA $\cdot$ Panulirus inflatus $\cdot$ Lobster $\cdot$ DNA sequencing Resale or republication not permitted without written consent of the publisher

\section{INTRODUCTION}

Blue spiny lobster Panulirus inflatus (Bouvier, 1895) is endemic to the tropical and subtropical Pacific coast of Mexico, from southern Baja California to Oaxaca, including some areas in the Gulf of California (see Fig. 1), where it inhabits rocky bottoms above $30 \mathrm{~m}$ depth (Pérez-González et al. 2002). The lobster is a valuable resource to the local fishery of many communities (Vega et al. 1996).

In spite of its economic importance, knowledge about the biology of species is scarce. Information on reproductive activity, size, and sex composition is known from some studies (Briones \& Lozano 1992,
Pérez-González et al. 1992a,b, Muñoz-García et al. 2000), which has led to management measures, including closed seasons, minimum legal size, and prohibition from catching egg-bearing females. More intensive studies of population dynamics and stock evaluation are needed to improve the management system (Pérez-González et al. 2002).

Better management strategies in the exploitation of a fishery resource should be based on the recognition of population boundaries. If the boundary of the fishery does not encompass a stock, adequate management may be affected because different growth and mortality characteristics of a population are not appropriately considered (Skillman 1989). Determination of popu- 
lation genetic structure has not been studied in blue spiny lobster and only limited data are available about disjunctive populations. García-Rodríguez et al. (2004) found significant differences in a multivariate morphometric analysis comparing the carapace of lobsters from the coast of the Baja California Peninsula and the coast of continental Mexico, suggesting that phenotypic plasticity is influenced by local differences in environmental factors rather than reproductive isolation.

Previous studies of population differences in other lobster species were based on allozyme analyses (Shaklee \& Samollow 1984, Hateley \& Sleeter 1993, Thompson et al. 1996, Perez-Enriquez et al. 2001). Recently, analysis of lineages based on mtDNA was used to evaluate population structure in this group of lobsters (Diniz et al. 2005, Triantafyllidis et al. 2005, García-Rodríguez \& Perez-Enriquez 2006). Analysis of mtDNA has been a useful tool to study the relationship between members of populations. Different mutation rates occurring in mtDNA allow us to explore interand intraspecific genetic variations. In spiny lobster, DNA sequencing of coding genes, such as $16 \mathrm{~S}$ and COI, has been used for phylogenetic reconstructions, supporting hypotheses based on morphological data to explain origins and radiation of the Panulirus genus (George \& Main 1967, Ptacek et al. 2001, George 2005). Sarver et al. (1998) showed that the $16 \mathrm{~S}$ gene clearly helped to discriminate between 2 clades of $P$. argus. The control region (also known as the 'AT-rich' region) in invertebrates - which does not code for a functional gene and therefore is under fewer functional and structural restrictions - leads to high average substitution rates (Saccone et al. 1987, Diniz et al. 2005), and has also proved to be useful for population genetic studies among crustaceans (Grabowski \& Stuck 1999, Chu et al. 2003, McMillenJackson \& Bert 2003, Grabowski et al. 2004, Diniz et al. 2005). Diniz et al. (2005), using the control region, showed that, in spite of the small sample size, there is very high diversity and genetic structure for $P$. argus concordant with that found using more conservative DNA sequences. Their data supports the idea that the control region has a high potential to be used in intraspecific variability studies in spiny lobsters.

For the present study, we collected blue spiny lobsters at 5 locations on the Pacific coast of Mexico to study genetic structure with mtDNA sequences. We included samples from the Baja California Peninsula to determine whether morphological differences in lobsters from Baja California and the mainland reflect genetic differences and reproductive isolation or phenotypic plasticity associated with local environmental differences.

\section{MATERIALS AND METHODS}

Sampling and DNA extraction. Lobsters were obtained from 5 local commercial fisheries in the Mexican states of Baja California Sur, Sinaloa, Nayarit, Jalisco, and Guerrero (Fig. 1) between September 2002 and May 2005. Lobsters from the Baja California Peninsula were captured in wooden traps; at the other locations, lobsters were collected with tangle nets or diving. After collection, muscle tissue from each specimen was preserved in $70 \%$ ethanol. Total genomic DNA was extracted by incubating muscle tissue overnight at $37^{\circ} \mathrm{C}$ in TNES buffer with Proteinase $\mathrm{K}$ and using a standard phenol-chloroform procedure as described in Perez-Enriquez \& Taniguchi (1999). Isolated DNA was suspended in $100 \mu \mathrm{l}$ TE buffer $(10 \mathrm{mM}$ Tris-HCl, 1 mM EDTA pH 7.6) and stored at $4^{\circ} \mathrm{C}$.

mtDNA amplification and sequencing. PCR was used to amplify 2 regions of mtDNA, a partial sequence of the $16 \mathrm{~S}$ gene $(543 \mathrm{bp}$ ) and the $12 \mathrm{~S}$ control region (12S-CR) fragment, composed of a putative fragment of the $12 \mathrm{~S}$ gene and a fragment of the control region (663 bp). In both cases, each PCR reaction was carried out in $50 \mu$ l containing PCR buffer $1 \mathrm{X}$ (Invitrogene), $0.2 \mathrm{mM}$ dNTP mix, $0.48 \mu \mathrm{M}$ of each primer, $4.0 \mathrm{mM} \mathrm{MgCl} 2$, and $2.5 \mathrm{U}$ Taq DNA polymerase (Invitrogene). The $12 \mathrm{~S}-\mathrm{CR}$ segment was amplified using the primer pair srRNA (5'-CAGGGTATCTAATCCTGGTT; Weider et al. 1996) and PinRC1-b (5'-GATGGCCCATTACCGAACTA; García-Rodriguez et al. 2008).

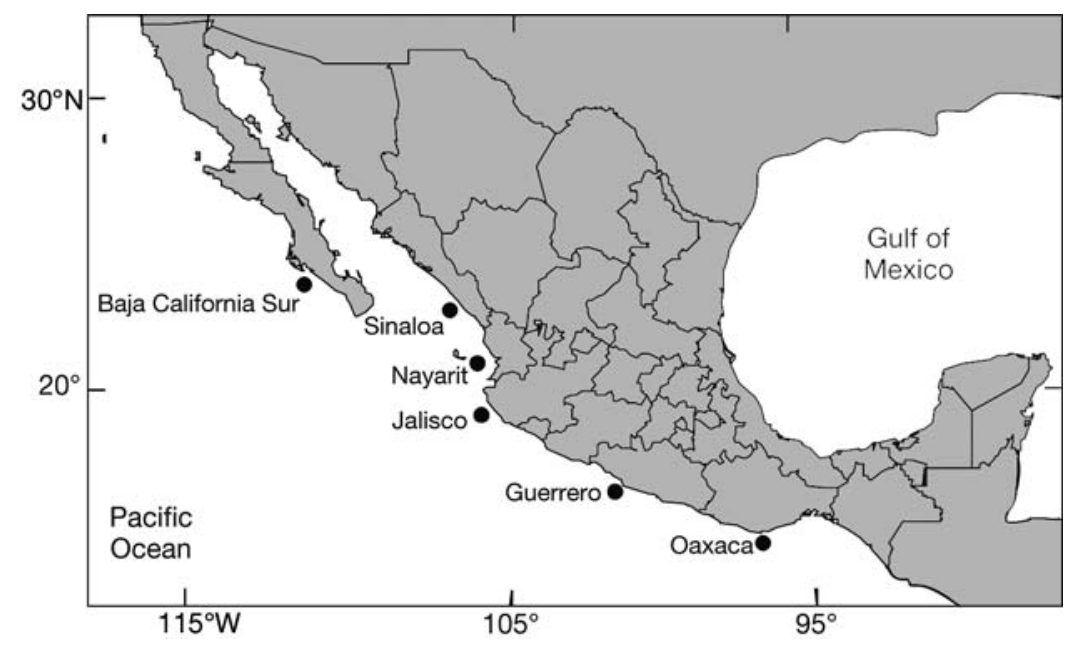

Fig. 1. Panulirus inflatus. Sampling locations along the Pacific coast of Mexico 
PCR thermal cycling involved an initial denaturation for $2 \mathrm{~min}$ at $94^{\circ} \mathrm{C}$, followed by 35 cycles for $1 \mathrm{~min}$ at $94^{\circ} \mathrm{C}, 1 \mathrm{~min}$ at $63^{\circ} \mathrm{C}$, and $2 \mathrm{~min}$ at $72^{\circ} \mathrm{C}$. A final cycle, lasting $4 \mathrm{~min}$, was done at $72^{\circ} \mathrm{C}$. The partial sequence of the $16 \mathrm{~S}$ gene was amplified, using primers 16Sar-L and 16Sbr-H (Palumbi et al. 1991). PCR thermal conditions were $2 \mathrm{~min}$ at $94^{\circ} \mathrm{C}, 30$ cycles for $1 \mathrm{~min}$ at $94^{\circ} \mathrm{C}$, $1 \mathrm{~min}$ at $60^{\circ} \mathrm{C}$, and $2 \mathrm{~min}$ at $72^{\circ} \mathrm{C}$. A final extension, lasting $4 \mathrm{~min}$ at $72^{\circ} \mathrm{C}$, was done. Amplification products underwent electrophoresis on $1 \%$ agarose gels and stained with SybrGold, along with a molecular weight marker, to confirm amplification and expected size. PCR products were purified and sequenced in sense and antisense (Macrogen). Individual sequences were deposited in GenBank (accession nos.: EF645361-EF645486 for 16S gene, and EF645487EF645597 for the 12S-CR fragment).

Data analysis. Sequences of each gene were arranged and overlapped using Sequencher v. 4.5 (GeneCode). Because of mutation rate differences between the control region and the $12 \mathrm{~S}$ gene, the $12 \mathrm{~S}-$ CR fragment was separated into the $12 \mathrm{~S}$ gene and the control region for each sequence, based on the sequence of Panulirus japonicus (GenBank accession no. NC 004251). Subsequent analyses were carried out with the 3 fragments separated (16S, 12S, and control region). Each gene sequence was aligned with MEGA v. 3.0 (Kumar et al. 2004), which uses the ClustalW algorithm. DnaSP v. 3 software was used to obtain unique haplotypes (Rozas et al. 2003). Haplotype and nucleotide diversity were estimated for each location using Arlequin v. 3.0 software (Excoffier et al. 2005). A minimum spanning network was constructed to review the genealogical relationship among the different haplotypes, using multi-state data as it is implemented in Network program 4.2.0.1 (available at www.fluxusengineering.com/sharenet.htm). A neighbor-joining phylogram based on the Kimura-2 parameter model (Kimura 1980) was constructed in MEGA v. 3.0 (Kumar et al. 2004), using P. laevicauda as the outgroup for $16 \mathrm{~S}$ (GenBank accession no. AF337969), since it is the phylogenetically closest species to P. inflatus. A chisquared test, based on Monte Carlo simulations (Roff \& Bentzen 1989), was used for 1000 iterations, using the Monte routine in REAP (McElroy et al. 1991) to determine whether haplotype heterogeneity among populations was statistically significant. Finally, we examined population structure by calculating genetic variation within and among populations using analysis of molecular variance (AMOVA). AMOVA was carried out by considering all localities as a single geographic region. Molecular pairwise $\Phi$ st (analogous to $F_{\mathrm{ST}}$ ) were estimated to evaluate genetic differentiation between pairs of populations. AMOVA and $\Phi$ st values were obtained using Arlequin v. 3.0 (Excoffier et al. 2005).
Mismatch distribution differences were estimated to review historical demography. The shape of the mismatch distribution is relevant because it may be used to deduce whether a population is undergoing sudden population expansion or is in equilibrium (Rogers \& Harpending 1992). In general, chaotic and multimodal distributions suggest a population of constant size, whereas unimodal distributions reflect a population that has experienced a sudden demographic expansion. Parameters of the model of sudden expansion $(\tau$, $\theta_{0}$, and $\theta_{1}$ ) and mismatch distribution differences were estimated using Arlequin v. 3.0 (Excoffier et al. 2005). Time of expansion was estimated according to Rogers \& Harpending (1992):

$$
t=\tau / 2 \mu
$$

where $t$ measures time in generations when a population expansion begins and $\mu$ is the specific fragment mutation rate. The parameters $\theta_{0}$ and $\theta_{1}$ measure the expected pairwise differences before and after the expansion. Goodness-of-fit between the observed distribution and expected distribution under the sudden expansion model was computed using Arlequin (Excoffier et al. 2005).

\section{RESULTS}

\section{Genetic diversity}

We obtained 113 sequences of the $16 \mathrm{~S}$ (543 bp) and 112 of the $12 \mathrm{~S}$-control region (325 and $338 \mathrm{bp}$ each) fragments. Measures of genetic variability showed that the most variable fragment was the control region and the least variable was the $16 \mathrm{~S}$ gene, with 80 distinct haplotypes identified in the control region, 40 in the $12 \mathrm{~S}$ gene, and 33 in the $16 \mathrm{~S}$ gene. The most frequent haplotype found in the control region (Hap-12) occurred 10 times, in the 12S gene (Hap-2) occurred 32 times, and in the 16S gene (Hap-5) occurred 44 times, which indicates lower dominance of a single haplotype in the control region compared to $12 \mathrm{~S}$ and $16 \mathrm{~S}$. Haplotype and nucleotide diversity were also higher in the control region than in the $12 \mathrm{~S}$ and 16S genes (Fig. 2; Table 1), indicating that population analysis of the blue spiny lobster was based on different levels of genetic variability. Haplotype diversity was relatively high, yet similar among the 5 locations (Table 1).

\section{Phylogeography and genetic structure}

The parsimony network of the $16 \mathrm{~S}$ gene showed that the single most frequent haplotype (Hap-5) was simi- 


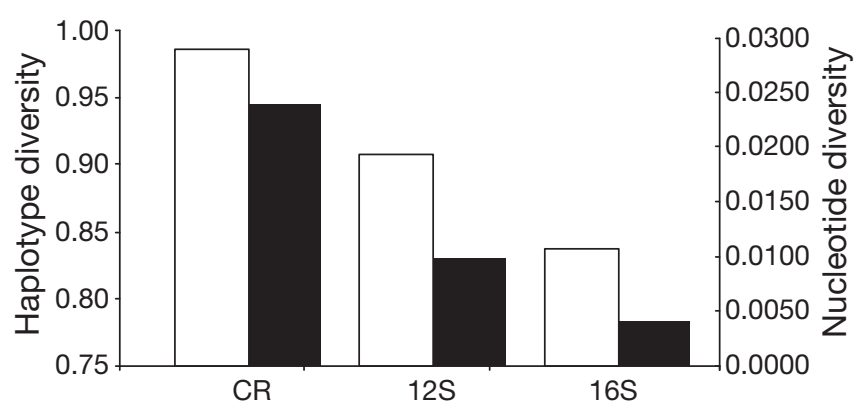

Fig. 2. Panulirus inflatus. Genetic diversity means estimated from $3 \mathrm{mtDNA}$ fragments. $\mathrm{CR}=$ control region. White: haplotype diversity; black: nucleotide diversity

larly shared among all localities (Fig. 3), which may also be the most ancestral. Adjacent haplotypes in the network differed by 1 or 2 mutational steps. No adjacent haplotype differed by $>2$ mutational steps. None of the clades was associated with a particular geographic area and rare haplotypes were indifferently connected with either of the 2 main lineages. Networks constructed from other mtDNA fragments were consistent with these observations (data not shown). None of the common haplotypes of each mtDNA fragment was geographically restricted, a pattern consistent with gene flow.

Phylogeographic analysis, based on neighborjoining, also showed low divergence along the Pacific coast of Mexico. None of the clades was clearly associated to a specific geographic region for the $16 \mathrm{~S}$ frag-

Table 1. Panulirus inflatus. Genetic diversity estimated for 3 mtDNA fragments at 5 localities. BCS = Baja California Sur; $\mathrm{N}=$ no. of haplotypes

\begin{tabular}{|lrrcc|}
\hline Locality & $\mathrm{n}$ & $\mathrm{N}$ & $\begin{array}{c}\text { Haplotype } \\
\text { diversity }\end{array}$ & $\begin{array}{c}\text { Nucleotide } \\
\text { diversity }\end{array}$ \\
\hline Control region & & & & \\
BCS & 20 & 18 & $0.990 \pm 0.019$ & $0.026 \pm 0.014$ \\
Sinaloa & 19 & 19 & $1.000 \pm 0.017$ & $0.028 \pm 0.015$ \\
Nayarit & 22 & 18 & $0.957 \pm 0.037$ & $0.019 \pm 0.011$ \\
Jalisco & 29 & 26 & $0.993 \pm 0.011$ & $0.022 \pm 0.012$ \\
Guerrero & 22 & 20 & $0.991 \pm 0.017$ & $0.024 \pm 0.013$ \\
12S & & & & \\
BCS & 20 & 17 & $0.979 \pm 0.025$ & $0.012 \pm 0.007$ \\
Sinaloa & 19 & 13 & $0.942 \pm 0.038$ & $0.012 \pm 0.007$ \\
Nayarit & 22 & 9 & $0.844 \pm 0.061$ & $0.007 \pm 0.005$ \\
Jalisco & 29 & 19 & $0.887 \pm 0.056$ & $0.009 \pm 0.005$ \\
Guerrero & 22 & 13 & $0.892 \pm 0.055$ & $0.009 \pm 0.005$ \\
16S & & & & \\
BCS & 24 & 10 & $0.804 \pm 0.070$ & $0.004 \pm 0.002$ \\
Sinaloa & 18 & 9 & $0.863 \pm 0.061$ & $0.004 \pm 0.003$ \\
Nayarit & 26 & 15 & $0.855 \pm 0.067$ & $0.005 \pm 0.003$ \\
Jalisco & 16 & 8 & $0.842 \pm 0.075$ & $0.004 \pm 0.002$ \\
Guerrero & 29 & 14 & $0.825 \pm 0.068$ & $0.004 \pm 0.002$ \\
\hline
\end{tabular}

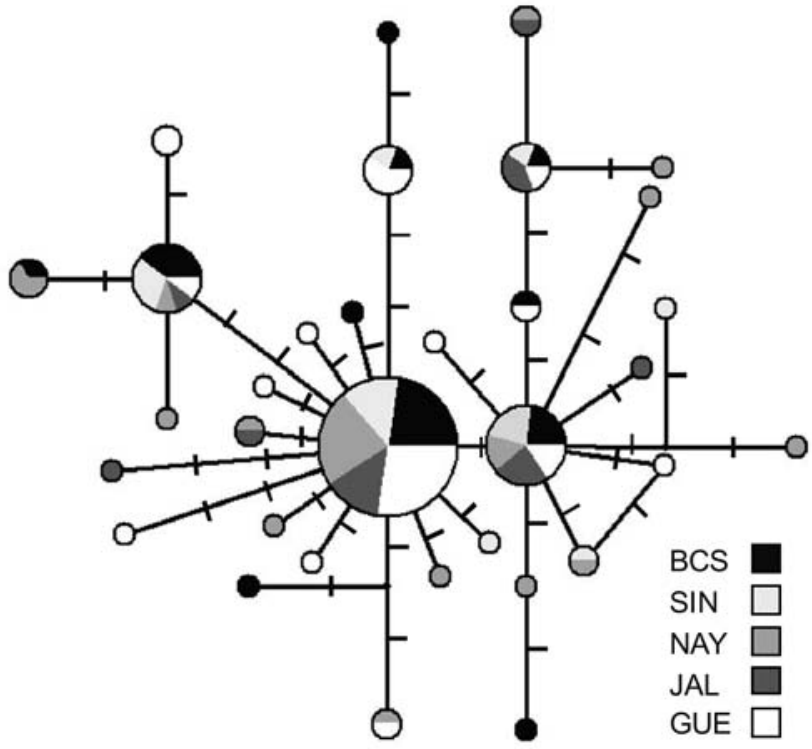

Fig. 3. Panulirus inflatus. Minimum spanning network obtained using $16 \mathrm{~S}$ sequences. Size of circle: relative frequency of haplotype. Transversal short lines between haplotypes: number of mutational steps between each pair haplotype. BCS = Baja California Sur, SIN $=$ Sinaloa, NAY $=$ Nayarit, $\mathrm{JAL}=$ Jalisco, GUE $=$ Guerrero

ment (Fig. 4), as occurred for the 12S fragment and control region (data not shown). Haplotype frequency distribution of each of the 3 fragments did not indicate a heterogeneous distribution among the 5 localities $\left(\chi^{2}=316.06, \mathrm{p}=0.787\right.$ for the control region; $\chi^{2}=$ $154.48, \mathrm{p}=0.570$ for the $12 \mathrm{~S}$ gene; $\chi^{2}=120.02, \mathrm{p}=$ 0.816 for the $16 \mathrm{~S}$ gene). AMOVA did not reveal a significant genetic difference among the 5 populations, as the percentage of variation explained by differences among populations was extremely low and not significantly different from 0 ( $\Phi$ st $=-0.0027, \mathrm{p}=0.555$ for the control region; $\Phi$ st $=-0.0011, \mathrm{p}=0.466$ for the $12 \mathrm{~S}$ gene; $\Phi$ st $=-0.00834, \mathrm{p}=0.759$ for the $16 \mathrm{~S}$ gene). A large proportion of the genetic variance was partitioned within populations. Pairwise $\Phi$ st was not significantly different between populations (Table 2). An additional sample $(\mathrm{n}=23)$ from Puerto Angel, Oaxaca (Fig. 1) obtained in November 2002 was included in the analysis using only $16 \mathrm{~S}$ sequences. Results also indicated genetic similarities throughout the distribution area $\left(\chi^{2}=174.05, \mathrm{p}=0.884 ;\right.$ Фst $=-0.0064, \mathrm{p}=$ 0.691).

\section{Demographic history}

The patterns of mismatch distribution and the orders of magnitude of the expansion model parameters were different among the 3 mtDNA fragments (Table 3 ). The 
mismatch distributions were unimodal in both $16 \mathrm{~S}$ and $12 \mathrm{~S}$ genes, although the shape of the distribution of the $16 \mathrm{~S}$ gene was relatively more similar among the localities than that of the 12S DNA fragment. The control region appeared somewhat multimodal in the 5 localities (Fig. 5). Nevertheless, the 'sudden expansion model' fitted all mismatch distributions, except for the control region at Sinaloa (Table 3); therefore, the hypothesis of a sudden population expansion could not be rejected. Apparent multimodal mismatch distribution of the control region could be indicative of a haphazard representation of haplotype lineages colonizing these areas. Similar demographic histories of spiny lobsters in this geographic area are seen from shapes of sequences of mismatch distribution, although the peaks of the distribution of $12 \mathrm{~S}$ were closer to the origin at southern locations. Parameters $\theta_{0}$ and $\theta_{1}$, estimated from $12 \mathrm{~S}$ and the control region in the 2 northern localities (particularly Baja California Sur), indicated that the expansion is faster than in southern localities (Nayarit, Jalisco, and Guerrero) (Table 3). The parameter $\theta_{1}$ showed a declining pattern from Baja California Sur to Nayarit, becoming relatively stable at southern locations.

\section{DISCUSSION}

Based on the differences in the number of haplotypes and genetic diversity of the analyzed fragments, different levels of genetic variability throughout the mtDNA were detected in the blue spiny lobster. The control region was the most variable fragment and $16 \mathrm{~S}$ the least variable. The control region is a noncoding region that includes the signals necessary for replication of the molecule and is the most rapidly evolving region of mtDNA (Heyer et al. 2001). Because of its high variability, it is commonly used to compare populations. The other 2 fragments were less variable, particularly the $16 \mathrm{~S}$ fragment. This gene is commonly used in phylogenetic analysis because it is a relatively well-conserved gene that allows comparisons of evolutionary lineages at the species level (Ovenden et al. 1997, Ptacek et al. 2001). In spite of the differences in genetic diversity in the 3 fragments, results from $12 \mathrm{~S}$ and $16 \mathrm{~S}$ also suggest that blue spiny lobster maintains high genetic variability that can be related to large population size, allowing increases in mutations and generating a greater number of allelic variants. High variability in other crustaceans has been offered as a cause for relatively elevated mutation rates (Palumbi \& Benzie 1991).
Since almost every individual represented a unique haplotype, an analysis based only on sequencing in the control region would require a very large sample size to detect common haplotypes and associate them to particular geographic areas.

We found similar genetic composition in the 3 mtDNA fragments among localities; genetic parameters (estimated using $\chi^{2}$, AMOVA, and pairwise $\Phi$ st) were not sufficiently different to show a clear phylogeographic pattern. Clades associated with particular geographic regions were not evident from these 3 mtDNA regions. Although morphometric differences were noticed between individuals from Baja California Peninsula and the continent (García-Rodríguez et al. 2004), they were not strong enough to suggest disjunctive populations. Instead, influences of local conditions are the most plausible reason to explain the differ-

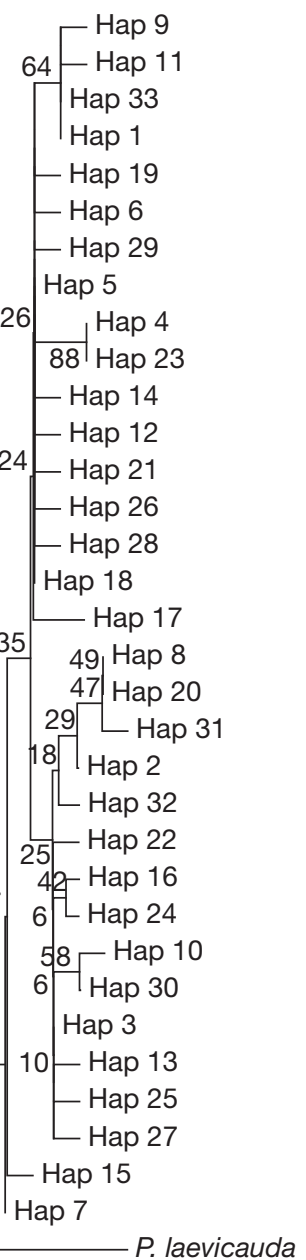

\begin{tabular}{|c|c|c|c|c|}
\hline BCS & SIN & NAY & JAL & GUE \\
\hline \multirow[t]{3}{*}{1} & & 2 & & \\
\hline & & & & 2 \\
\hline & & 1 & & \\
\hline \multirow[t]{2}{*}{4} & 3 & 1 & 1 & 1 \\
\hline & & & 1 & \\
\hline \multirow[t]{2}{*}{1} & & & & \\
\hline & & 1 & & \\
\hline 10 & 6 & 10 & 6 & 12 \\
\hline \multirow[t]{9}{*}{1} & 1 & & & 3 \\
\hline & 1 & & & \\
\hline & & & & 1 \\
\hline & & & & 1 \\
\hline & & 1 & 1 & \\
\hline & 1 & & & \\
\hline & & 1 & & \\
\hline & 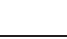 & & & 1 \\
\hline & & & & 1 \\
\hline \multirow[t]{3}{*}{1} & & 1 & 2 & 1 \\
\hline & & 1 & 1 & \\
\hline & & 1 & & \\
\hline \multirow[t]{5}{*}{1} & & & & 1 \\
\hline & & 1 & & \\
\hline & & & 1 & \\
\hline & & & & 1 \\
\hline & 1 & 1 & & \\
\hline \multirow[t]{2}{*}{1} & & & & \\
\hline & & 1 & & \\
\hline \multirow[t]{5}{*}{3} & 3 & 2 & 3 & 2 \\
\hline & & & & 1 \\
\hline & 1 & & & \\
\hline & & 1 & & \\
\hline & & 1 & & 1 \\
\hline 1 & & & & \\
\hline
\end{tabular}

Fig. 4. Panulirus inflatus. Neighbor-joining tree based on $16 \mathrm{~S}$ sequences and haplotype frequencies. $\mathrm{BCS}=$ Baja California Sur, $\mathrm{SIN}=$ Sinaloa, $\mathrm{NAY}=$ Nayarit, JAL $=$ Jalisco, GUE $=$ Guerrero 
Table 2. Panulirus inflatus. Pairwise $\Phi$ st (below) and corresponding $\mathrm{p}$ values (above). BCS = Baja California Sur

\begin{tabular}{llccccc}
$\begin{array}{l}\text { mtDNA } \\
\text { fragment }\end{array}$ & Locality & BCS & Sinaloa & Nayarit & Jalisco & Guerrero \\
\hline Control & BCS & - & 0.958 & 0.473 & 0.418 & 0.381 \\
region & Sinaloa & -0.024 & - & 0.165 & 0.154 & 0.121 \\
& Nayarit & -0.005 & 0.018 & - & 0.906 & 0.854 \\
& Jalisco & -0.002 & 0.017 & -0.018 & - & 0.925 \\
& Guerrero & 0.002 & 0.021 & -0.017 & -0.018 & - \\
& & & & & & \\
$12 S$ & BCS & - & 0.894 & 0.345 & 0.482 & 0.288 \\
& Sinaloa & -0.025 & - & 0.078 & 0.209 & 0.220 \\
& Nayarit & 0.003 & 0.035 & - & 0.954 & 0.459 \\
& Jalisco & -0.004 & 0.013 & -0.025 & - & 0.921 \\
& Guerrero & 0.008 & 0.016 & -0.003 & -0.019 & - \\
& & & & & & \\
& BCS & - & 0.930 & 0.931 & 0.186 & 0.659 \\
& Sinaloa & -0.029 & - & 0.849 & 0.322 & 0.857 \\
& Nayarit & -0.022 & -0.020 & - & 0.586 & 0.476 \\
& Jalisco & 0.023 & 0.004 & -0.011 & - & 0.157 \\
& Guerrero & -0.011 & -0.021 & -0.003 & 0.022 & - \\
\hline
\end{tabular}

Table 3. Panulirus inflatus. Parameter of historical demography of 5 distribution localities and goodness-of-fit test for 3 mtDNA fragments. BCS = Baja California Sur, $\mathrm{SSD}=$ sum of squared deviations, $\mathrm{RAG}=$ raggedness index of Harpending

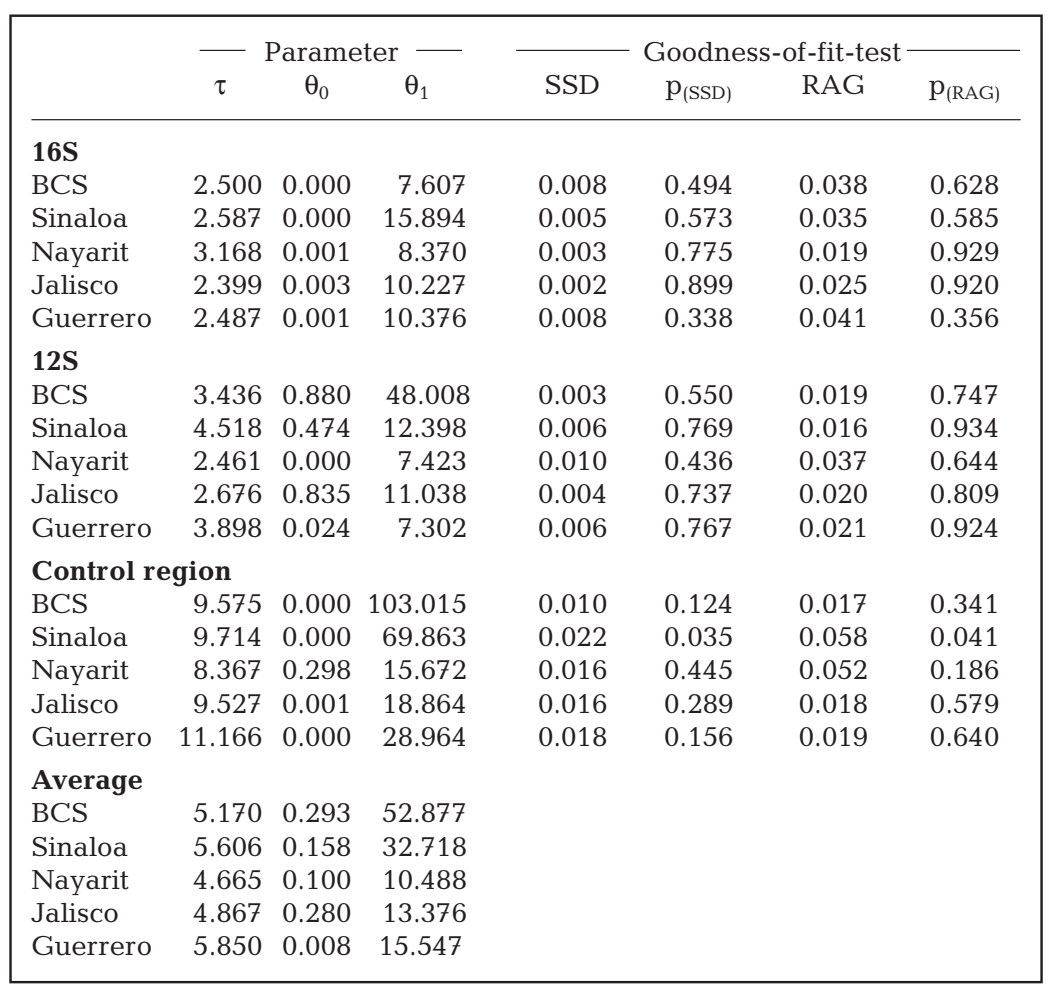

In a study of the Caribbean spiny lobster Panulirus argus from the Caribbean and Brazil, Sarver et al. (1998) used the same partial sequence from $16 \mathrm{~S}$ to distinguish 2 completely separate populations, which are considered subspecies ( $P$. argus argus in the Caribbean and $P$. argus westonii in Brazil). They associated genetic isolation to oceanographic conditions (reduced salinity and high turbidity) present near the mouths of a series of rivers, as geographic barriers to larval dispersion and postlarval settlement. Such genetic differentiation does not exist in the blue spiny lobster, because there are no barriers along the coast of the peninsula and the mainland, even though they are separated by 220 to $250 \mathrm{~km}$ of open sea at the mouth of the Gulf of California. Our results are probably a consequence of 2 conditions: oceanographic currents in the Eastern Pacific and the long larval stage of this lobster. In other species, minuscule population differentiation was found in P. marginatus (Shaklee \& Samollow 1984), $P$. argus (Hateley \& Sleeter 1993), $P$. cygnus (Thompson et al. 1996), and $P$. interruptus (García-Rodríguez \& PerezEnriquez 2006). In these cases, marine circulation and the long larval stage were suggested as the primary basis for the similarities.

Circulation in the Eastern Pacific is complex. Two marine currents play an important role in distribution of lobster larvae. The California Current flows south along the Baja California Peninsula and gradually turns west to feed the North Equatorial Current. Its intensity changes during the year. From January to June, but mainly in spring, the California Current flows southeast to $13^{\circ} \mathrm{N}, 105^{\circ} \mathrm{W}$, then turns westward. From July to December, the current is very weak and has little influence on the North Equatorial Current (Wyrtki 1967, Badan 1997, Kessler 2006). The West Mexican Current flows north-

ences. The genetic similarities suggest high genetic flow among lobsters along the Pacific Coast, from the Baja California Peninsula to Oaxaca, and support the model that morphological differences are mainly a consequence of phenotypic plasticity. westward, increasing its speed from June to October, when more tropical water is transported to the Gulf of California (Kessler 2006). The California Current and the West Mexican Current intensify their directional pattern, although in an opposite way, depending on 


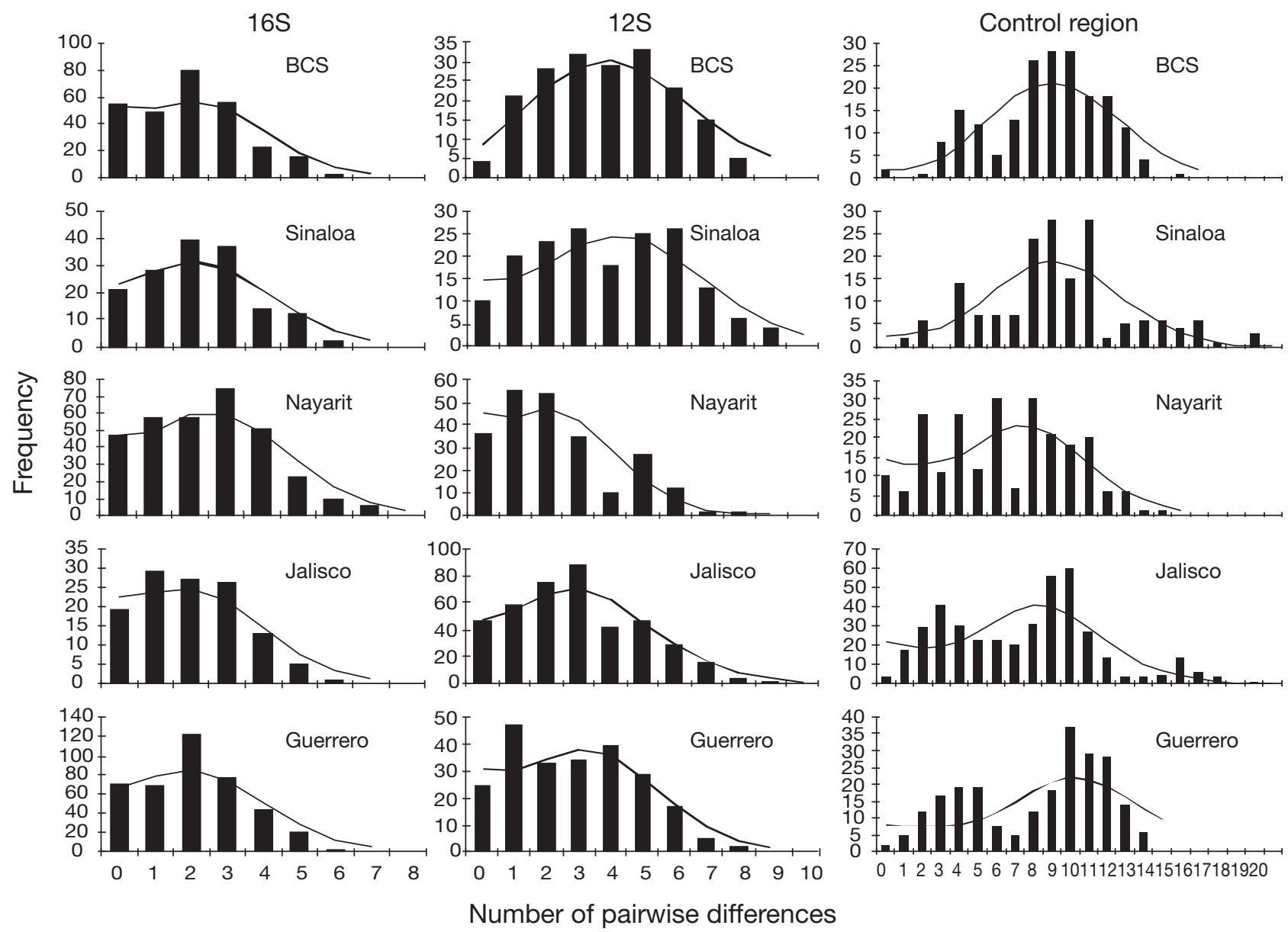

Fig. 5. Panulirus inflatus. Mismatch distribution from each fragment mtDNA for 5 sampling sites. Bars represent observed distribution and lines represent expected distribution according to the sudden expansion models. BCS = Baja California Sur

the absence or presence of El Niño Southern Oscillation (ENSO) (Kessler 2006). Oceanographic processes that vary seasonally and yearly are clearly important in the larval drift and partly explain genetic homogenization of discrete blue lobster populations. Johnson (1974) found larvae of green spiny lobster Panulirus gracilis west of the Galapagos Islands, showing a strong influence of the currents on dispersion and distribution. Genetic homogeneity might be strongly related to the extended phyllosoma larval stage that drifts for 6 to 11 mo (Johnson 1960). Mature blue spiny lobster has at least 2 spawnings each year, so that larvae are present throughout the year (Pérez-González et al. 1992b, Muñoz-García et al. 2000) and move at the mercy of the California Current and West Mexican Current.

In the eastern tropical Pacific Ocean, other invertebrates show genetic differentiation. Valles-Jimenez et al. (2004) found a genetic structure in whiteleg shrimp Litopenaeus vannamei that they attribute to local oceanographic processes (major water currents, a warm water pool, and winter winds) and the duration of the larval stage ( $2 \mathrm{wk}$ in the open sea before entering coastal lagoons), factors that do not fully apply to lobster. Bernardi et al. (2003) found 2 phylogeographic patterns for 12 fish species in the Gulf of California and along the west coast of the Baja California Peninsula. Eight of these species had discrete populations (Pattern 1) and 4 had high genetic flow (Pattern 2). Larval dispersion, vicariance (geographic barriers), and ecological factors explained their findings.

Historical analysis suggests that expansion demographic processes have occurred along the distribution area of blue spiny lobster. If that is the consequence of the resurgence of small isolated populations passing through expansion events, one should expect to see the signature of genetic drift affecting the haplotype frequencies, which in our case revealed no significant differentiation across the range. The mutational-drift equilibrium timescales for these loci can be such that 
they might not be able to detect differentiation among subpopulations given the historical population expansion. However, previous information better supports the idea that blue spiny lobster conforms to a single panmictic population that expands throughout its range.

In general, demographic history, inferred from mismatch distribution, suggests expansion patterns that are relatively similar among the 5 localities. However, some differences might be inferred from the $12 \mathrm{~S}$ fragment, where northern localities (Baja California Sur and Sinaloa) share a right-shifted unimodal mismatch distribution that suggests that these localities may be relatively older and the 3 southern localities share a left-shifted unimodal mismatch distribution that may indicate a more recent common demographic history (Rogers \& Harpending 1992). Diversity data are consistent with this idea. We calculated the average ratio $\pi / \mathrm{H}$ (nucleotide/haplotype diversity) and found lower values in the southern locations (Fig. 6), which also suggests a shorter history of haplotypes. High haplotype diversity and close genetic distance among haplotypes is interpreted as evidence of more recent population expansion, presumably since insufficient time has expired to generate enough nucleotide differences (Cassone \& Boulding 2006). Moreover, the 3 southern localities have an average parameter-of-expansion model $\theta_{1}$ that is lower by several orders of magnitude, reflecting a slower population increase relative to northern locations (Table 1).

From our results, sudden population expansion suggests that mtDNA haplotype frequencies have not yet reached equilibrium; blue spiny lobster might be colonizing newly available habits. In turn, blue spiny lobster is regarded as a divergence from the Panulirus gracilis stock in the north, settling in a new habitat in and around the Gulf of California when the Baja California Peninsula initially separated from mainland Mexico in the late Miocene (George 2005). Northern

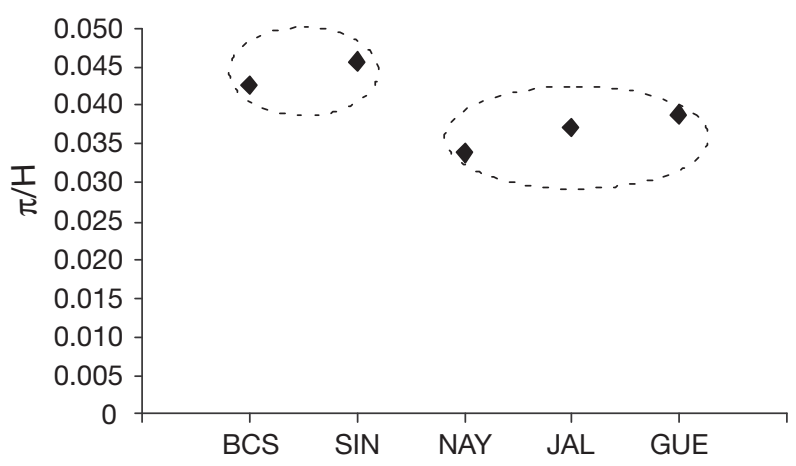

Fig. 6. Panulirus inflatus. Relationship between average of nucleotide and haplotype diversity for each locality. BCS = Baja California Sur, SIN = Sinaloa, NAY = Nayarit, JAL $=$ Jalisco, GUE $=$ Guerrero colonization facilitated expansion into new habitats and settlement in areas as distant as the western coast of Baja California Peninsula. The ocean current system, existing since the Pliocene, played an important role in the selection process for settling of blue spiny lobster (George 2005). Later, the 4 glacial episodes of the Pleistocene may have contributed to genetic homogenization by forcing the contraction and permitting the expansion of the species' range, as sea level and sea surface temperature rose and fell.

To estimate the time when range expansion occurred, we used the $\tau$ parameters of the model of sudden population expansion calculated from the $16 \mathrm{~S}$ gene and the divergence rate of 0.88 to $2.2 \%$ every million years that was estimated for the $16 \mathrm{~S}$ of marine crustaceans (Cunningham et al. 1992, Schubart et al. 1998). Based on the long larval stage, growth rate, and size at maturity, the generation time for Panulirus inflatus is $\sim 2.5 \mathrm{yr}$ (M. Villalejo-Fuerte pers. comm.). From these 'clock' calibrations, range expansion of the 5 locations was between 55369 and 73078 yr. These estimates correspond to the last glacial period, suggesting that conditions at that time influenced colonization of the desired habitats.

Our analysis suggests that the blue spiny lobster is a panmictic species that can be treated as a single management unit for fishery purposes. While further studies on short-term connectivity would complement this view, coordinated efforts should be carried out among capture sites to focus on maintaining local stocks to ensure long-term conservation of blue spiny lobster and its fishery.

Acknowledgements. We thank A. Vega, E. Espino, R. M. Gutiérrez, and E. Cabrera of the National Fisheries Institute of Mexico for providing specimens from Baja California Sur, Jalisco, and support for sampling in Guerrero, respectively. We also thank R. Pérez-González (FACIMAR-UAS) for his support during sampling in Sinaloa and Nayarit. This study was funded by a grant from SAGARPA-CONACYT (2003C01-129) to R.P.E.; F.J.G.R. was a CONACYT doctoral fellow.

\section{LITERATURE CITED}

Badan A (1997) La Corriente Costera de Costa Rica en el Pacifico mexicano. In: Lavin ML (ed) Contribuciones a la oceanografía física de México. Monografía No. 3, Unión Geofísica Mexicana, Mexico City, p 99-112

> Bernardi G, Findley L, Rocha-Olivares A (2003) Vicariance and dispersal across Baja California in disjunct marine fish populations. Evolution 57:1599-1609

Briones P, Lozano E (1992) Aspects of the reproduction of Panulirus inflatus (Bouvier) and P. gracilis Strets (Decapoda: Palinuridae) from the Pacific coast of Mexico. J Crustac Biol 12:41-50

Cassone BJ, Boulding EG (2006) Genetic structure and phylogeography of the lined shore crab, Pachygrapsus crassipes, along the northeastern and western Pacific coasts. Mar Biol 149:213-222 
Chu KH, Li CP, Tam YK, Lavery S (2003) Application of mitochondrial control region in population genetic studies of the shrimp Penaeus. Mol Ecol Notes 3:120-122

Cunningham CW, Blackstone NW, Buss LW (1992) Evolution of king crabs from hermit crab ancestors. Nature 355: $539-542$

> Diniz FM, Maclean N, Ogawa M, Cintra IHA, Bentzen P (2005) The hypervariable domain of the mitochondrial control region in Atlantic spiny lobsters and its potential as a marker for investigating phylogeographic structuring. Mar Biotechnol 7:462-473

Excoffier L, Laval G, Schneider S (2005) Arlequin ver. 3.0: an integrated software package for population genetics data analysis. Evol Bioinform Online 1:47-50

García-Rodríguez FJ, Perez-Enriquez R (2006) Genetic differentiation of the California spiny lobster Panulirus interruptus (Randall, 1840) along the west coast of the Baja California Peninsula, Mexico. Mar Biol 148:621-629

García-Rodríguez FJ, De la Cruz-Agüero J, Perez-Enriquez R, MacLeod N (2004) Morphometric analysis of population differentiation and sexual dimorphism in the blue spiny lobster Panulirus inflatus (Bouvier, 1895) from NW Mexico. In: Elewa AMT (ed) Morphometrics: applications in biology and paleontology. Springer-Verlag, Berlin, p 29-43

García-Rodríguez FJ, Ponce-Díaz G, Muñoz-García I, González-Armas R, Perez-Enriquez R (2008) Mitochondrial DNA markers to identify commercial spiny lobster species (Panulirus spp.) from the Pacific coast of Mexico: an application on phyllosoma larvae. Fish Bull 106: 204-212

George RW (2005) Tethys Sea fragmentation and speciation of Panulirus spiny lobsters. Crustaceana 78:1281-1309

George RW, Main AR (1967) The evolution of spiny lobster (Palinuridae): a study of evolution in the marine environment. Evolution 21:803-820

Grabowski M, Stuck KC (1999) Structure and intraspecific variability of the control region mtDNA in the pink shrimp, Farfantepenaeus duorarum (Decapoda, Penaeidae). In: Schram FR, von Vaupel Klein JC (eds) Crustaceans and the biodiversity crisis, Vol I. Brill Academic Publishers, Leiden, p 333-344

Grabowski M, Grater WD, Stuck KC (2004) A novel polymorphic mtDNA marker for population studies of the pink shrimp, Farfantepenaeus duorarum (Crustacea, Penaeidae). Oceanologia 46:147-151

Hateley JG, Sleeter TD (1993) A biochemical genetic investigation of spiny lobster (Panulirus argus) stock replenishment in Bermuda. Bull Mar Sci 52:993-1006

Heyer E, Zietkiewicz E, Rochowski A, Yotova V, Puymirat J, Labuda D (2001) Phylogenetic and familial estimates of mitochondrial substitution rates: study of control region mutations in deep-rooting pedigrees. Am J Hum Genet 69:1113-1126

Johnson MW (1960) The offshore drift of larvae of the California spiny lobster Panulirus interruptus. Calif Coop Ocean Fish Investig Rep 7:147-161

Johnson MW (1974) On the dispersal of larvae into the east Pacific barrier (Decapoda, Palinuridae). Fish Bull (Wash DC) 72:639-647

Kessler WS (2006) The circulation of the eastern tropical Pacific: a review. Prog Oceanogr 69:181-217

Kimura M (1980) A simple method for estimating evolutionary rate of base substitutions through comparative studies of nucleotide sequences. J Mol Evol 16:111-120

Kumar S, Tamura K, Nei M (2004) MEGA 3: Integrated software for molecular evolutionary genetics analysis and sequence alignment. Brief Bioinform 5:150-163
McElroy D, Moran P, Bermingham E, Kornfield I (1991) The restriction enzymes analysis package v. 4. Department of Zoology Migratory Fish Research Institute and Center for Marines Studies, University of Maine, Orono

> McMillen-Jackson AL, Bert TM (2003) Disparate patterns of population genetic structure and population history in two sympatric penaeid shrimp species (Farfantepenaeus aztecus and Litopenaeus setiferus) in the eastern United States. Mol Ecol 12:2895-2905

Muñoz-García I, Pérez-González R, Flores-Campaña LM, Borrego MI (2000) Distribución y abundancia de filosomas de Panulirus (Decapada: Palinuridae) en el sureste del Golfo de California, México. Rev Biol Trop 48:159-167

> Ovenden JR, Booth JD, Smolenski AJ (1997) Mitochondrial DNA phylogeny of red and green rock lobster (genus Jasus). Mar Freshw Res 48:1131-1136

Palumbi SR, Benzie J (1991) Large mitochondrial DNA differences between morphologically similar Penaeid shrimp. Mol Mar Biol Biotechnol 1:27-34

Palumbi SR, Martin A, Romano S, McMillan WO, Stice L, Grabowski G (1991) A simple fools guide to PCR, v. 2.0. University of Hawaii Department of Zoology and Kewalo Marine Laboratory

Perez-Enriquez R, Taniguchi N (1999) Genetic structure of red sea bream (Pagrus major) population off Japan and the Southwest Pacific, using microsatellite DNA marker. Fish Sci 1:23-30

Perez-Enriquez R, Vega A, Avila S, Sandoval JL (2001) Population genetics of red spiny lobster (Panulirus interruptus) along the Baja California Peninsula, Mexico. Mar Freshw Res 52:1541-1549

Pérez-González R, Flores-Campaña LM, Núñez-Pasten A (1992a) Análisis de la distribución de tallas, captura y esfuerzo en la pesquería de las langostas Panulirus inflatus (Bouvier, 1985) y P. gracilis Streets, 1871 (Decapoda: Palinuridae) en las costas de Sinaloa, México. Proc S Diego Soc Nat Hist 15:1-5

Pérez-González R, Flores-Campaña LM, Núñez-Pasten A, Ortega-Salas A (1992b) Algunos aspectos de la reproducción en Panulirus inflatus (Bouvier) y P. gracilis Streets (Decapoda: Palinuridae) en el sureste del Golfo California, México. Invest Mar 7:25-33

Pérez-González R, Muñoz I, Valadez LM, Borrego ML (2002) The current status of the fishery for spiny lobsters Panulirus inflatus and P. gracilis (Decapoda: Palinuridae) along the Mexican Pacific coast. In: Hendrickx ME (ed) Contributions to the study of east Pacific crustaceans. Instituto de Ciencias del Mar y Limnología, Universidad Nacional Autónoma de México, Mexico City

Ptacek MB, Sarver SK, Childress MJ, Herrnkind WF (2001) Molecular phylogeny of the spiny lobster genus Panulirus (Decapoda: Palinuridae). Mar Freshw Res 52:1037-1047

Roff DA, Bentzen P (1989) The statistical analysis of mitochondrial DNA polymorphisms: $\chi^{2}$ and the problem of small samples. Mol Biol Evol 6:539-545

> Rogers AR, Harpending H (1992) Population growth waves in the distribution of pairwise genetic differences. Mol Biol Evol 9:552-569

> Rozas J, Sánchez-Del Barrio JC, Messeguer X, Rozas R (2003) DnaSP, DNA polymorphism analyses by the coalescent and other methods. Bioinformatics 19:2496-2497

Saccone C, Attimonelli M, Sbisa E (1987) Structural elements highly preserved during the evolution of the D-loopcontaining region in vertebrate mitochondrial DNA. J Mol Evol 26:205-211

Sarver SK, Silberman JD, Walsh PJ (1998) Mitochondrial DNA sequence evidence supporting the recognition of 
two subspecies or species of the Florida spiny lobster Panulirus argus. J Crustac Biol 18:177-186

Schubart CD, Diesel R, Hedges B (1998) Rapid evolution to terrestrial life in Jamaican crabs. Nature 393:363-365

Shaklee JB, Samollow PB (1984) Genetic variation and population structure in a spiny lobster, Panulirus marginatus, in the Hawaiian Archipelago. Fish Bull 82: 693-702

Skillman RA (1989) Stock identification and billfish management. In: Stroud RH (ed) Planning the future of billfishes: research and management in the 90 s and beyond. Part 1. Fishery and stock synopses, data needs and management. Marine Recreational Fisheries 13 - Proc 2nd Int Billfish Symp, Kailua-Kona, Hawaii, August 1-5, 1988. National Coalition for Marine Conservation, Savannah, GA, p 207-214

Thompson AP, Hanley JR, Johnson MS (1996) Genetic structure of western rock lobsters, Panulirus cygnus, with the benefit of hindsight. Mar Freshw Res 47:889-896

Editorial responsibility: Don Levitan,

Tallahassee, Florida, USA
Triantafyllidis A, Apostolidis AP, Katsares V, Nelly E and others (2005) Mitochondrial DNA variation in the European lobster (Homarus gammarus) throughout the range. Mar Biol 146:223-235

Valles-Jimenez R, Cruz P, Perez-Enriquez R (2004) Population genetic structure of the Pacific white shrimp (Litopenaeus vannamei) from Mexico to Panama: microsatellite DNA variation. Mar Biotechnol 6:475-484

Vega VA, Espinoza-Castro G, Gómez-Rojo C (1996) Pesquería de la langosta Panulirus spp. In: Casas-Valdez M, Ponce-Diaz G (eds) Estudio del potencial pesquero y acuícola de Baja California Sur. CIBNOR, Baja California Sur, Mexico, p 227-261

Weider LJ, Hobaek A, Crease TJ, Stibor H (1996) Molecular characterization of clonal population structure and biogeography of arctic apomictic Daphnia from Greenland and Iceland. Mol Ecol 5:107-118

Wyrtki K (1967) Circulation and water mass in the eastern equatorial Pacific Ocean. Int J Oceanol Limnol 1:117-147

Submitted: July 18, 2006; Accepted: December 20, 2007

Proofs received from author(s): May 15, 2008 